\title{
7-Dehydrocholesterol-dependent proteolysis of HMG-CoA reductase suppresses sterol biosynthesis in a mouse model of Smith-Lemli-Opitz/RSH syndrome
}

\author{
Barbara U. Fitzky, ${ }^{1}$ Fabian F. Moebius, ${ }^{1}$ Hitoshi Asaoka, ${ }^{2}$ Heather Waage-Baudet, ${ }^{3}$ \\ Liwen Xu, ${ }^{4}$ Guorong Xu, ${ }^{2}$ Nobuyo Maeda, ${ }^{5}$ Kimberly Kluckman, ${ }^{5}$ Sylvia Hiller, ${ }^{5}$ \\ Hongwei Yu, ${ }^{6}$ Ashok K. Batta, ${ }^{2}$ Sarah Shefer, ${ }^{2}$ Thomas Chen, ${ }^{7}$ Gerald Salen, ${ }^{2,8}$ \\ Kathleen Sulik, ${ }^{3}$ Robert D. Simoni, ${ }^{4}$ Gene C. Ness, ${ }^{9}$ Hartmut Glossmann, ${ }^{1}$ \\ Shailendra B. Patel, ${ }^{6}$ and G.S. Tint ${ }^{2,8}$ \\ ${ }^{1}$ Institute of Biochemical Pharmacology, Innsbruck, Austria \\ ${ }^{2}$ Department of Medicine and Liver Center, UMDNJ-New Jersey Medical School, Newark, New Jersey, USA \\ ${ }^{3}$ Department of Cell Biology and Anatomy, University of North Carolina at Chapel Hill, Chapel Hill, North Carolina, USA \\ ${ }^{4}$ Department of Biological Sciences, Stanford University, Palo Alto, California, USA \\ ${ }^{5}$ Department of Pathology, University of North Carolina at Chapel Hill, Chapel Hill, North Carolina, USA \\ ${ }^{6}$ Division of Endocrinology, Diabetes and Medical Genetics, Department of Medicine, Medical University of South Carolina, \\ Charleston, South Carolina, USA \\ ${ }^{7}$ Laboratory Service, and \\ ${ }^{8}$ Research Service and Medical Service, Department of Veterans Affairs Medical Center, East Orange, New Jersey, USA \\ ${ }^{9}$ Department of Biochemistry and Molecular Biology, College of Medicine and the Institute for Biomolecular Sciences, \\ University of South Florida College of Medicine, Tampa, Florida, USA
}

Address correspondence to: G.S. Tint, VA Medical Center, 385 Tremont Avenue, East Orange, New Jersey 07018, USA. Phone: (973) 395-7180; Fax: (973) 676-2991; E-mail: tintgs@umdnj.edu.

Barbara U. Fitzky and Fabian F. Moebius contributed equally to this work.

Received for publication January 3, 2001, and accepted in revised form July 30, 2001.

\begin{abstract}
Smith-Lemli-Opitz/RSH syndrome (SLOS), a relatively common birth-defect mental-retardation syndrome, is caused by mutations in DHCR7, whose product catalyzes an obligate step in cholesterol biosynthesis, the conversion of 7-dehydrocholesterol to cholesterol. A null mutation in the murine $D h c r 7$ causes an identical biochemical defect to that seen in SLOS, including markedly reduced tissue cholesterol and total sterol levels, and 30- to 40-fold elevated concentrations of 7-dehydrocholesterol. Prenatal lethality was not noted, but newborn homozygotes breathed with difficulty, did not suckle, and died soon after birth with immature lungs, enlarged bladders, and, frequently, cleft palates. Despite reduced sterol concentrations in $\mathrm{Dhcr} 7^{-/-}$mice, mRNA levels for 3-hydroxy-3-methylglutaryl coenzyme A (HMG-CoA) reductase, the rate-controlling enzyme for sterol biosynthesis, the LDL receptor, and SREBP-2 appeared neither elevated nor repressed. In contrast to mRNA, protein levels and activities of HMG-CoA reductase were markedly reduced. Consistent with this finding, 7-dehydrocholesterol accelerates proteolysis of HMG-CoA reductase while sparing other key proteins. These results demonstrate that in mice without Dhcr7 activity, accumulated 7-dehydrocholesterol suppresses sterol biosynthesis posttranslationally. This effect might exacerbate abnormal development in SLOS by increasing the fetal cholesterol deficiency.
\end{abstract}

J. Clin. Invest. 108:905-915 (2001). DOI:10.1172/JCI200112103.

\section{Introduction}

A number of birth defect-malformation syndromes, first characterized by their clinical features, have since proven to be metabolic disorders caused by abnormalities in enzymes essential for cholesterol biosynthesis (1-6). The most common of these, with an estimated frequency of 1 in 10,000 to 40,000 Caucasian births (7-9), is Smith-Lemli-Opitz/RSH syndrome (SLOS; MIM 270400) (10) characterized by a dysmorphic facial appearance; palatal clefting; twothree toe syndactyly; postaxial polydactyly; malformations of heart, kidney, genitalia, and lungs; occa- sional holoprosencephaly; severe to profound mental retardation; and failure to thrive $(10,11)$. SLOS is caused by mutations in DHCR7, the gene that codes for $3 \beta$-hydroxysteroid $\Delta^{7}$-reductase (E.C.1.3.1.21), the enzyme that catalyzes the reduction of the $\Delta^{7}$ double bond of 7-dehydrocholesterol (7DHC) (cholesta-5,7dien-3 $\beta$-ol) to form cholesterol (cholest-5-en-3 $\beta$-ol) $(12-15)$. As a result, cholesterol biosynthesis is hindered, leading to reduced plasma and tissue cholesterol concentrations and the accumulation of 7DHC and its epimer 8DHC (cholesta-5,8-dien-3 $\beta$-ol) in all tissues $(12,16-18)$. 
Cholesterol plays an essential role in development because it is needed to activate the morphogenic sonic hedgehog $(\mathrm{SHH})$ signal pathway during early gestation (19), and adverse effects of cholesterol deprivation in the prenatal period are amply illustrated in SLOS by the strong inverse dependence of symptom severity and perinatal mortality on plasma cholesterol levels $(8,20)$. In contrast to cholesterol, 7DHC fails to stimulate the SHH pathway (21). 7DHC also appears to be an especially potent inhibitor of 3-hydroxy-3-methylglutaryl coenzyme A (HMG-CoA) reductase (22), the rate-limiting enzyme for cholesterol biosynthesis, explaining why plasma total sterol and mevalonic acid concentrations $(16,23,24)$ and rates of sterol biosynthesis, as measured by sterol balance (25), are reduced by an average of $40-50 \%$ in SLOS.

To explore the mechanisms by which 7DHC inhibits sterol biosynthesis, the mouse $D h c r 7$ gene was mutated by homologous recombination to create an animal lacking measurable Dhcr7 activity. Except for low $8 \mathrm{DHC} / 7 \mathrm{DHC}$ ratios, the biochemical phenotype in the mice was indistinguishable from that in SLOS, and several physical and metabolic abnormalities found in newborn $\mathrm{Dhcr} 7^{-/-}$mice have their counterparts in affected children. As in SLOS, sterol biosynthesis was highly abnormal in homozygous mice. HMG-CoA reductase, LDL receptor, and sterol response element-binding protein-2 (SREBP-2) mRNA levels were found to be similar to levels measured in heterozygous and wild-type littermates, yet tissue total sterol concentrations and HMG-CoA reductase protein levels and activities were markedly reduced. Ancillary in vitro studies provided the explanation for this seemingly paradoxical result, demonstrating that 7DHC accelerates proteolysis of HMG-CoA reductase enzyme several fold. Thus, in the Dhcr7-null mouse, as in children with SLOS, elevated concentrations of 7DHC suppress cholesterol synthesis, exacerbating the sterol deficiency and further contributing to abnormal development.

\section{Methods}

Generation of Dhcr $7^{-/-}$mice $\left(D h c r 7^{\text {Ex8 }}\right)$. A genomic cosmid clone from mouse strain 1290la (clone MPMGc121P1353Q3) containing the entire Dhcr7 gene was obtained from the Resource Centre/Primary Database (Berlin, Germany) (15). The targeting construct in pBluescript KSII (Figure 1a) contained two fragments of genomic Dhcr7 DNA, a 1.6-kb neomycin resistance gene under control of the phosphoglycerokinase (PGK) promoter from pKO SelectNeo (Lexicon Genetics, The Woodlands, Texas, USA) in opposite orientation to the transcription of $\mathrm{Dhcr} 7$ and a $2-\mathrm{kb}$ thymidine kinase gene from pKO SelectTK (Lexicon Genetics). The 5'-region of homology was a $6.6-\mathrm{kb}$ Dhcr 7 ClaI-SfuI fragment comprising mouse exons 4-7 (corresponding to human exons 5-8). The 3 '-region of homology was a $1.4-\mathrm{kb}$ EcoRI-SpeI fragment that included the entire $3^{\prime}$ untranslated region of exon 8 (corresponding to human exon 9) and an additional nontranscribed genomic sequence (Figure 1a). Electroporation of embryonic stem (ES) cells (E14TG2a) was carried out as described (26). Four correctly targeted ES cell clones were identified by PCR and homologous recombination was confirmed by Southern blot analysis. C57Bl/ 6 blastocysts were injected with the correctly targeted ES cells and implanted into pseudopregnant $\mathrm{C} 57 \mathrm{Bl} / 6$ females. Chimeric mice were identified by their coat color (agouti) and bred. Several pups carrying the modified Dhor 7 gene were identified, indicating that the mutation had passed into their germ cells. For genotype analysis, 450 bp of exon 8 of the wild-type gene was amplified using primer a, $5^{\prime}$ ggatcttctgagggcagcctt, and primer b, $5^{\prime}$ tctgaaccttggctgatca, while the 320-bp fragment of the mutant allele was amplified by primers neo, $5^{\prime}$ ctagaccgcggctagagaat, and primer b (Figure 1a).

Immunoblot analysis of Dhcr7 expression was carried out by separating proteins on $14 \%$ SDS-polyacrylamide gels, then analyzing them by immunoblotting with $1 \mathrm{mg} / \mathrm{ml} \alpha$-DHCR7 $454-467$ as described previously (15). Loading of the gels with total liver protein over a range 80:1 results in corresponding reductions in Dhcr7 antibody response (Figure 1d, upper panel). In the lower panel of Figure 1d, microsomal protein from yeast strains (WA0) and human tsA-201 cells (tsA) heterologously expressing DHCR7 with an Nterminal myc tag (15) and from livers of newborn mice of the indicated genotype were separated. Equal loading was verified by coincubation with antibodies against the $\sigma_{1}$-receptor (control) as described (15). No DHCR7 was detected in mock-transfected yeast (MOCK), while the level of immunoreactive protein was markedly increased in transfected compared with mock-transfected tsA cells.

Affinity-purified polyclonal Ab's ( $\alpha$-DHCR7 $454-467$ ), raised in rabbits against amino acid residues 454-467 (YGRDWERYTAAVPY) of human DHCR7, were purchased from BioChem Pharm (Salzburg, Austria).

Biochemical measurements. Sterols were purchased from Steraloids Inc. (Newport, Rhode Island, USA), except 7dehydrodesmosterol (cholesta-7,24-dien-3 $\beta$-ol), which was obtained from the plasma of a rat 72 hours after the simultaneous administration of the $\Delta^{7}$-reductase inhibitor BM 15.766 and the $\Delta^{24}$-reductase inhibitor triparanol. Tissue sterols were measured as their trimethylsilyl ether derivatives using capillary column gas chromatography (GC) $(12,27)$, while microsomal sterols, sterols from cultured cells, and 7DHC in $\mathrm{Dhcr} 7^{+/-}$and wild-type pups were quantitated using $\mathrm{GC} /$ selected ion-monitoring mass spectrometry by measuring the intensities of the 329,325 , and $343 \mathrm{~m} / \mathrm{z}$ peaks for cholesterol, 7DHC, and desmosterol, respectively $(22,28)$. Because 7DHC and desmosterol have similar GC retention times 7DHC levels in tissues from $D h c r 7^{+/-}$and wild-type animals, especially brain, were corrected for the presence of desmosterol by using $325: 343 \mathrm{~m} / z$ ratios. Glucose was measured with a Fast Take glucometer in blood obtained by decapitation less than 12 hours after birth. 
Enzyme activities. Dhcr7 activity was assayed by a modification of the method described by Shefer et al. (13) because we found it necessary to use whole tissue homogenate rather than microsomes to achieve reproducible results. Briefly, $0.5 \mathrm{mg}$ protein was incubated in $150 \mu \mathrm{l}$ of $100 \mathrm{mM}$ phosphate buffer ( $\mathrm{pH}$ 7.4) containing a NADPH-generating system plus $30 \mathrm{nmol}$ of $\left[{ }^{3} \mathrm{H}\right]-7 \mathrm{DHC}(25,000 \mathrm{dpm})$. HMG-CoA reductase activities were measured in isolated liver and brain microsomes as described previously (29).

Measurement of $m R N A$. Total RNA was extracted from freshly harvested liver with Trizol (Life Technologies, Bethesda Maryland, USA), according to the manufacturer's recommendation and Northern analysis performed as described previously (30). Mouse cDNA probes for HMG-CoA reductase, HMG-CoA synthase, LDL receptor (LDLR), and squalene synthase have been described previously (30) and were gifts from Hitoshi Shimano and Jay Horton (University of Texas Southwestern Medical Center, Dallas, Texas, USA). Dhcr7 mRNA was measured by RT-PCR after first isolating total RNA from $5 \mathrm{mg}$ of mouse liver and brain, then carrying out oligo dT-primed reverse transcription of 2 $\mu \mathrm{g}$ of RNA followed by PCR using the sense/antisensespecific primer pair for the $3^{\prime}$ transcript of Dhor7 (915: 5'gaccatcgacatctgccatgacc/ 1870: 5 'ggagcctagctcaccaggatgg; fragment size: $955 \mathrm{bp}$ ). GAPDH mRNA was obtained from the same aliquots of reverse-transcribed cDNA using PCR with the specific sense/antisense primer pairs $5^{\prime}$ cagtatgactccactcacg/5'atcgaaggtggaagagtgg (fragment size $747 \mathrm{bp}$ ). Signal intensities were quantified by phosphorimaging analysis after background subtraction, and all were normalized to the signal obtained with GAPDH.

$H M G-C o A$ reductase and LDLR protein immunoblotting. Fifty micrograms of liver homogenate was subjected to SDS gel electrophoresis on $7.5 \%$ slab gels (31). The separated proteins were transferred to PVDF Plus membranes, blocked with 5\% nonfat dry milk in PBS-Tween, incubated for 2 hours with a 1:5,000 dilution of HMGCoA reductase (32) or LDLR antisera (33), then incubated for 1 hour with a 1:100,000-diluted goat anti-rabbit IgG conjugated with horseradish peroxidase (The Jackson Laboratory, Bar Harbor, Maine, USA). Reductase immunoreactive protein was detected with an ECL kit (Amersham Pharmacia Biotech Inc., Piscataway, New Jer- a

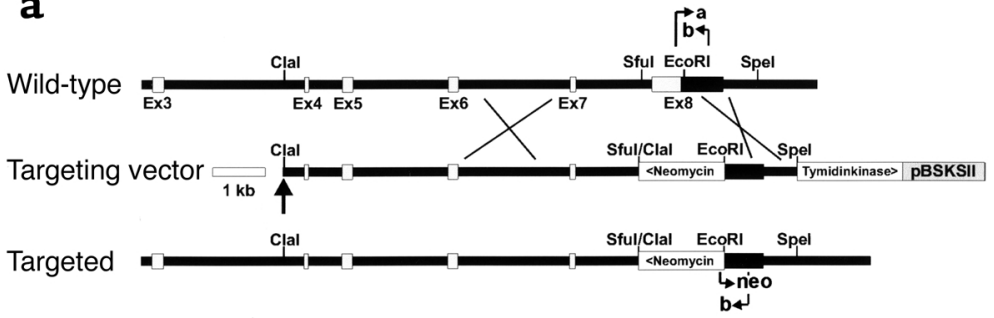

b

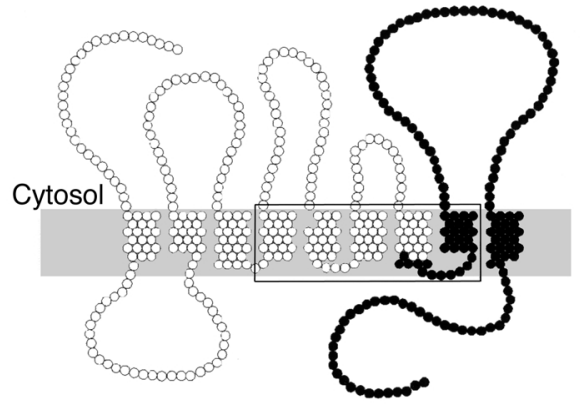

d

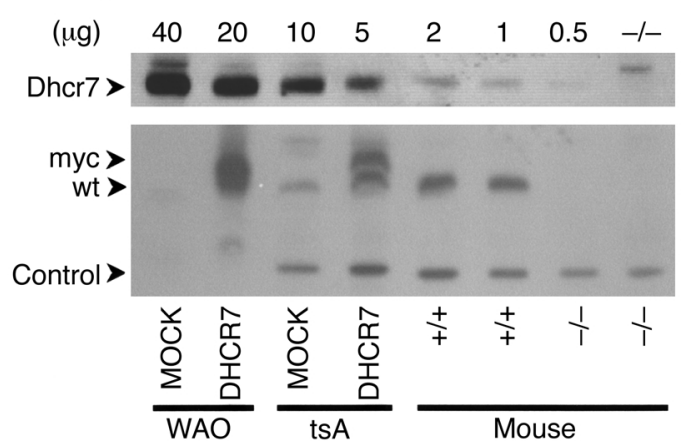

Figure 1

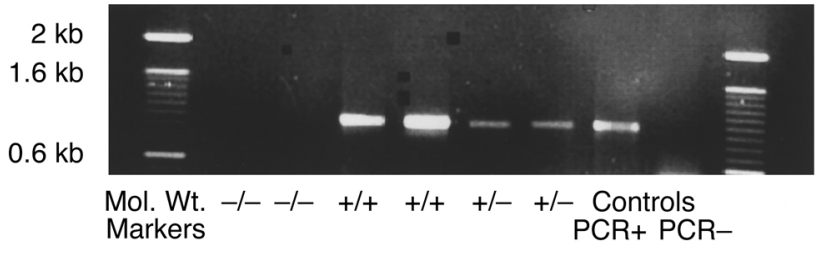

(a) Disruption of the Dhcr7 gene. The coding sequence of exon 8 and the $5^{\prime}$ flanking splice acceptor site and part of the 3' flanking untranslated region (indicated in gray) of the wild-type gene were replaced with a neomycin resistance gene in opposite orientation to $D h c r 7$ transcription. Restriction sites used for subcloning of short and long Dhcr 7 gene segments are shown. The targeting construct was linearized with Clal (arrow). Primers employed for PCR genotyping are labeled a, b, and neo (see Methods). (b) Tentative topology model of Dhcr7. The induced Dhcr7 mutation is expected to delete one-third of the Dhcr7 protein (the residues shown as filled circles). The box indicates the putative sterol-binding site REF. (c) Total RNA extracted from the livers of $D h c r 7^{-/-}, D h c r 7^{+/-}$, and wild-type newborn mice was reverse transcribed and amplified using specific primers for the 3'-end of Dhcr7 mRNA and GADPH. (d) Immunoblot analysis of Dhcr7. Upper panel: Loading decreasing amounts of total hepatic protein results in corresponding reductions in Dhcr7 Ab response. Lower panel: Microsomal protein from yeast (WA0) and human tsA-201 cells (tsA) heterologously expressing DHCR7 with an N-terminal myc tag (15) and from livers of newborn wild-type mice demonstrated immunoreactive Dhcr7 protein. Bands corresponding to myc-tagged (myc) and wild-type (WT) DHCR7/Dhcr7 proteins, respectively, are indicated by arrowheads. In contrast, no immunoreactive band corresponding to wild-type Dhcr7 was detected in $40 \mu \mathrm{g}$ of microsomal protein from either homozygous mice (last two lanes) or mock-transfected yeast (MOCK). 


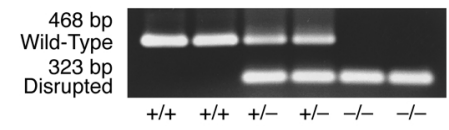

Figure 2

Genotyping of $\mathrm{Dhcr} 7^{-/-}, \mathrm{Dhcr} 7^{+/-}$, and $\mathrm{Dhcr} \mathrm{7}^{+/+}$newborn mice from heterozygous matings by PCR using primers specific for mouse exons 7 and 8 as described in Methods and in Figure $1 \mathrm{a}$.

sey, USA). Membranes were stripped then reprobed with a 1:5,000 dilution of $\beta$-actin $\mathrm{Ab}$ (Sigma Chemical Co., St. Louis, Missouri, USA). The amount of immunoreactive HMG-CoA reductase protein present was determined with an Image Quant 5.1 System.

In vitro measurements of $H M G-C o A$ reductase enzyme catabolism. Stability of HMG-CoA reductase was studied in an in vitro system developed by Simoni and colleagues, which employs a fusion gene ( $H M G$ al) consisting of exons coding for the transmembrane domain of HMG-CoA reductase coupled to the $\beta$-galactosidase promoter and gene stably transfected into Chinese hamster ovary $(\mathrm{CHO})$ cells. In this system the $\beta$-galactosidase activity acts as a reporter for HMG-CoA reductase protein levels and activities (34). A pTRE HMGal plasmid was generated by insertion of full-length HMGal cDNA sequences (EcoRI/Xbal fragment) into a pTRE-Off vector (CLONTECH Laboratories Inc., Palo Alto, California, USA), then cotransfected with pTK Hyg DNA (CLONTECH Laboratories Inc.) into stable Tet-Off CHO-AA8 cells (CLONTECH Laboratories Inc.) in a ratio of 20:1 by lipofection using a Lipofectamine PLUS kit (Life Technologies Inc.), according to the manufacturer's instructions. Transfectants were selected with $0.6 \mathrm{mg} / \mathrm{ml}$ hygromycin $\mathrm{B}$ for 14 days, and resistant colonies with the highest $\beta$-galactosidase activity were isolated using fluorescence-activated cell sorting (35). Cells were maintained in 5\% FBS minimal essential medium (FBS-MEM) supplemented with nonessential amino acids, $0.1 \mathrm{mg} / \mathrm{ml}$ active G418, and $0.2 \mathrm{mg} / \mathrm{ml}$ hygromycin $\mathrm{B}$ in a humidified $5 \% \mathrm{CO}_{2}$ incubator at $37^{\circ} \mathrm{C}$, and passaged every 3 days until use.

To measure $\beta$-galactosidase activity (34) cells were seeded as triplicates in 24-well dishes with 5\% FBS-MEM. After incubating for 20 hours, they were then treated with 5\% lipid-poor fetal calf serum-MEM (LPS-MEM) (36) supplemented with $10 \mu \mathrm{M}$ compactin (a generous gift from Akira Endo, Tokyo Noko University, Tokyo, Japan), $0.1 \mathrm{mM}$ sodium mevalonate, and various concentrations of 7DHC or cholesterol. After an additional 20-hour incubation, cells were permeabilized with $50 \mu \mathrm{g} / \mathrm{ml}$ digitonin and incubated at $37^{\circ} \mathrm{C}$ with a $1 \mathrm{mg} / \mathrm{ml}$ concentration of the colorimetric enzyme substrate $o$-nitrophenyl $\beta$-o-galactopyranoside until a color change was visually detectable. Reactions were stopped by addition of $1 \mathrm{M} \mathrm{Na}_{2} \mathrm{CO}_{3}$, and specific activity values were calculated by normalization to time of incubation and total protein (37). Specific activity values are the mean of three independent experiments.
HMG-CoA reductase and HMGal protein degradation rates were determined in pulse-chase experiments as described previously (38). Cells were grown in $60-\mathrm{mm}$ dishes to $70-80 \%$ confluence in 5\% FBS-MEM. The following day, the medium was changed to 5\% LPS-MEM medium containing $10 \mu \mathrm{M}$ compactin and $0.1 \mathrm{mM}$ sodium mevalonate with or without the addition of 7DHC or cholesterol. After a 20-hour incubation, cells were starved for 1 hour in methionine/cysteine-free MEM supplemented with $10 \mu \mathrm{M}$ compactin, $0.1 \mathrm{mM}$ sodium mevalonate, and 7DHC or cholesterol, then labeled for 0.5 hour in methionine/cysteine-free MEM containing $10 \mu \mathrm{M}$ compactin, $0.1 \mathrm{mM}$ sodium mevalonate, $100 \mu \mathrm{Ci}$ of Tran 35S-label, and 7DHC or cholesterol. Cells were chased in $5 \%$ LPS-MEM containing $10 \mu \mathrm{M}$ compactin, $0.1 \mathrm{mM}$ sodium mevalonate, $2 \mathrm{mM}$ methionine, $2 \mathrm{mM}$ cysteine, and 7DHC or cholesterol to various time points. At each time point, cells were washed and solubilized, HMG-CoA reductase and HMGal proteins immunoprecipitated with anti-membrane domain HMGR Ab's and anti- $\beta$-galactosidase $\mathrm{mAb}$ 's. The immunoprecipitated $\left[{ }^{35} \mathrm{~S}\right]$-labeled HMG-CoA reductase and HMGal proteins were resolved by 5 to $15 \%$ gradient SDS-PAGE and quantified by fluorography and densitometry.

In addition, because we had reported that ketoconazole, an inhibitor of sterol side-chain hydroxylation, appeared to blunt the suppressive effects of 7DHC on HMG-CoA reductase activity in cultured fibroblasts (22), HMGal catabolism was also measured in the presence of $10 \mu \mathrm{g} / \mathrm{ml}$ 7DHC plus $30 \mu \mathrm{M}$ ketoconazole.

To quantify HMG-CoA reductase catabolic rates, the data were transformed to protein half-live values as follows. The quantity of ${ }^{35} \mathrm{~S}$ in immunoprecipitated HMGCoA reductase or HMGal following a chase with unlabeled methionine was assumed to decline according to first-order kinetics so that ${ }^{35} \mathrm{~S}$ activity $=S_{0} \exp (-\alpha t)$. Halflives were calculated by converting the percentage of radioactivity remaining at each time point $t$ to its natural $\log$, plotting $\ln \left({ }^{35} \mathrm{~S}\right.$ activity) against time, estimating the resulting slope $\alpha$ by a least-squares fit, then comparing slopes by one-way analysis of covariance (RS/1; Brooks Automation Inc., Chelmsford, Massachusetts, USA), stratifying according to the concentration of added 7DHC. The half-life was set equal to $(\ln 2) / \alpha$, and, to allow for nonlinearity at the earliest time points, the ordinate was not fixed at $100 \%$ but the least-squares process was allowed to find a best fit for $S_{0}$.

Statistics. Concentrations and activities are expressed as mean plus or minus SD with differences assessed by the student's $t$ test or ANOVA, where appropriate, and significance accepted when $P$ values were less than 0.05 .

Animals. Except where noted, all pups were killed within the first day and either examined under a dissecting microscope, or their tissues were removed immediately, placed on dry ice, and reserved for further analysis. Care was taken to harvest tissues only from living animals and to transfer them immediately to dry ice. It was, however, impossible to compare the relative physical conditions of the newborn $D h c r 7^{-/}$pups 


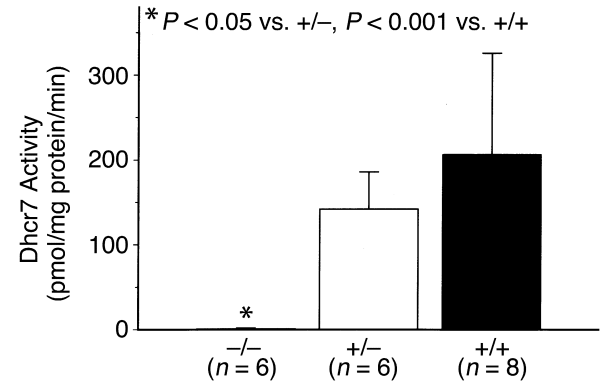

Figure 3

Activity of Dhcr7 (picomoles per milligram of protein per minute) as measured by the conversion of $\left[{ }^{3} \mathrm{H}\right]-7 \mathrm{DHC}$ to cholesterol in liver homogenates from newborn $\mathrm{Dhcr} 7^{-l_{-}^{-}}, \mathrm{Dhcr} \mathrm{T}^{+/-}$, and $\mathrm{Dhcr} \mathrm{T}^{+/+}$mice.

because they all appeared to be inert but still breathing. Matings were of $\mathrm{F}_{1}, \mathrm{~F}_{2}$, and $\mathrm{F}_{3}$ heterozygotes and controls were newborn $\mathrm{Dhcr} 7^{7^{+-}}$and $\mathrm{Dhcr} 7^{+/+}$pups. Experiments were carried out under protocols approved by the institutional animal care and use committees of the University of North Carolina at Chapel Hill, Medical University of South Carolina, the Bundesministerium für Wissenschaft und Forschung (Innsbruck, Austria), Veterans Affairs Medical Center (East Orange, New Jersey, USA), and UMDNJ-New Jersey Medical School.

\section{Results}

Targeted mutation of the Dhcr 7 locus eliminates enzyme activity. The most frequently encountered DHCR7 mutation in SLOS patients (IVS8-1G $\rightarrow$ C) causes aberrant splicing of the last exon and leads to a frameshift and truncation of the gene product (15). The few SLOS patients homozygous for this defect are among the most severely affected SLOS patients, and the mutation appears to be a null allele (18). To completely inactivate Dhcr7 we created a mutation analogous to IVS8-1G $\rightarrow$ C by deleting the last exon (exon 8) and its flanking splice acceptor site in the mouse gene (Figure 1a), thereby removing the sequence for amino acid residues 318-471 (Figure 1b) that code for approximately one-third of the protein. This deletion prevents transcription of two putative transmembrane segments that contain part of a predicted sterol-sensing domain and an extended hydrophilic sequence thought to form a large cytosolic loop (39). Analysis of genomic DNA (Figure 2) verified the engineered genomic alterations shown in Figure 1a. As expected from the nature of the targeted Dhcr 7 mutation, RT-PCR could not amplify the deleted $3^{\prime}$-coding region of $D h c r 7$ mRNA in liver (Figure 1c) or brain (not shown) from pups homozygous for the $D h c r 7^{\text {delExs }}$ allele while Dhcr7-specific Ab's failed to detect the Dhcr7 protein in $D b c r 7^{-/}$mice (Figure 1d). In contrast, $5^{\prime}$-exonic regions of $D h c r 7$, which were not deleted by the mutation, were amplified successfully (data not shown), indicating that the targeted gene was transcribed. Dhcr7 activities from homozygous newborns were virtually undetectable $(1 \pm 1 \mathrm{pmol} / \mathrm{mg}$ protein $/ \mathrm{min})$, while enzyme activities in heterozygotes were close to half of that noted in wild-type mice (Figure 3).
Dhcr ${ }^{4 E \times 8}$ mice display developmental abnormalities and die perinatally. Heterozygous matings resulted in litters that averaged 6-7 animals (range 2-12) yielding 61 homozygotes, 130 heterozygotes, and 60 wild-type animals in 251 consecutive newborns (approximately half male and half female) examined within 14 hours of birth. As this result closely approximates the expected Mendelian ratio, homozygotes do not die prenatally. Pups lacking Dhcr7 activity, however, were easily identified shortly after birth by their labored breathing, blue coloration, and lack of movement, while heterozygous and wild-type littermates appeared to be identical in physical appearance and size to each other. None of the $\mathrm{Dhcr} 7^{-/}$pups suckled, and they weighed significantly less $(P<0.001)$ than their $\mathrm{Dhcr} 7^{+/-}$and wild-type littermates $(1.14 \pm 0.10 \mathrm{~g}, n=15$, vs. $1.41 \pm 0.15 \mathrm{~g}, n=38$, and $1.42 \pm 0.13 \mathrm{~g}, n=17$, respectively). Blood glucose levels $(92 \pm 11,94 \pm 17$, and $96 \pm 21 \mathrm{mg} / \mathrm{dl}$, respectively; $P=\mathrm{NS}$ ) were similar in all animals. All homozygotes died within 18 hours, presumably from respiratory failure or dehydration. Histological analysis showed no gross abnormalities of brain, heart, intestine, adrenal gland, or kidney. However, microscopic examination of fixed and stained sections of lung sections from $\mathrm{Dhcr} 7^{-/-}$mice demonstrated compact lungs with sparse, unconnected air spaces (Figure 4) that were similar in appearance to normal 15 - to 16 -gestational day mice (40). These results suggest that lungs in newborn $\mathrm{Dhcr} 7^{-/-}$mice may be immature and would explain their breathing difficulties and
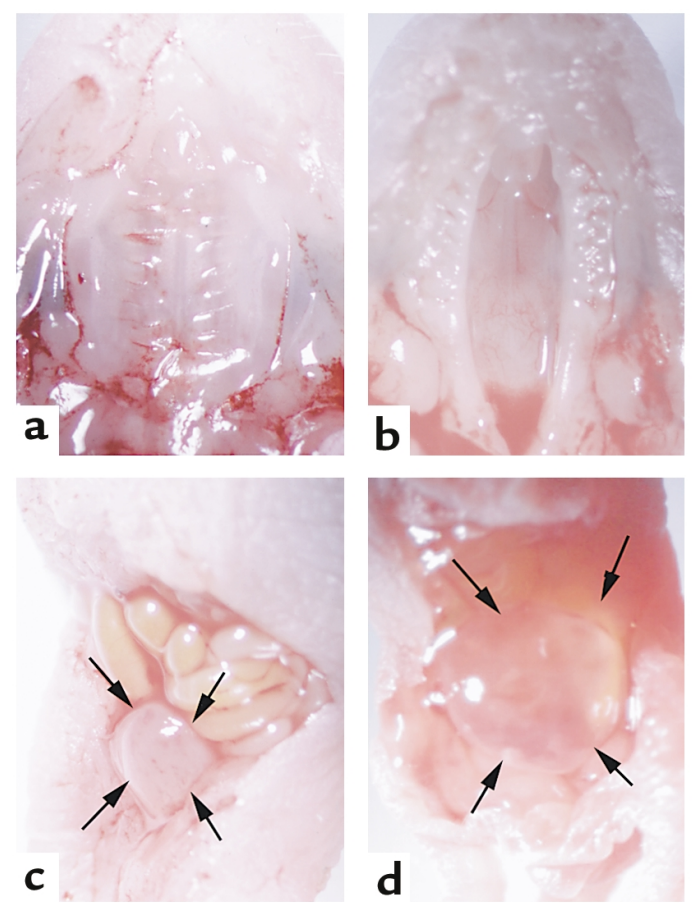

Figure 4

Palates were unremarkable in newborn $\mathrm{Dhcr} \mathrm{T}^{+/-}$and $\mathrm{Dhcr} \mathrm{7}^{+/+}$mice (a) but were frequently cleft in $D h c r 7^{-1-}$ newborns (b), while bladders were of normal size in controls (c) but were nearly always distended (indicated by arrows in the opened abdomen) in $\mathrm{Dhcr} 7^{-/-}$mice (d). $\times 10$. 


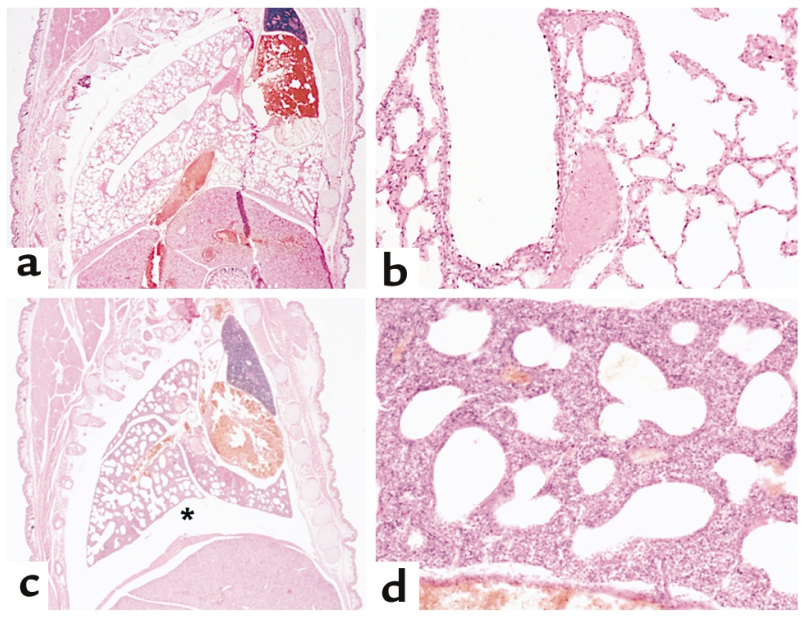

Figure 5

Histological sections of control mouse lung, $(\mathbf{a}) \times 10$ and $(\mathbf{b}) \times 40$, and $D h c r 7^{-/-}$mouse lung, (c) $\times 10$ and (d) $\times 40$, illustrating lung hypoplasia in the latter. Especially noteworthy is the excessive cellular density, the failure of the lungs to fill the pleural cavity $\left({ }^{*}\right)$, and their immature appearance.

early death. Although not seen in any $\mathrm{Dhcr} 7^{+/-}$or $\mathrm{Dhcr} 7^{+/+}$littermates, isolated cleft palates were noted in $12 \%$ of $\mathrm{Dbcr} 7^{-/-}$pups (Figures 5, a and b), while more than $90 \%$ of $\mathrm{Dhcr} 7^{-/-}$newborns but no $\mathrm{Dhcr} 7^{+/-}$or $D h c r 7^{+/+}$mice exhibited greatly distended urinary bladders (Figures 5, c and d).

Sterol abnormalities in Dhcr $7^{-1-}$ mice and bumans with SLOS are similar. Cholesterol and total sterol (cholesterol plus dehydrocholesterol) concentrations were significantly reduced, while levels of 7DHC and 8DHC were increased 30- to 40-fold in isolated liver microsomes, in whole liver, and in brain homogenates from Dhcr $7^{-/}$newborn mice (Table 1). Except for $8 \mathrm{DHC} / 7 \mathrm{DHC}$ ratios that were lower than those noted in humans $(16,20)$, sterol compositions in $\mathrm{Dhcr} 7^{-1}$ mice closely resembled that in SLOS. Cholesterol deficits in homozygous mice were most profound in the brain with dehydrocholesterols making up $80 \%$ of total sterols. Furthermore, although desmosterol (cholesta-5,24-dien-3 $\beta$-ol) constituted nearly $20 \%$ of neutral sterols in the $\mathrm{Dhcr} 7^{+/-}$and $\mathrm{Dhcr}^{7^{+/+}}$newborn mouse brain, this cholesterol precursor was not detected in $\mathrm{Dhcr}^{-/-}$mice, which instead accumulated 7-dehydrodesmosterol (cholesta-5,7,24-trien-3 $\beta$-ol).

Plasma cholesterol levels, $111 \pm 27 \mathrm{mg} / \mathrm{dl}$ and $82 \pm 16$ in heterozygous breeders and wild-type adult mice, respectively $(n=6, P=\mathrm{NS})$, were similar. Liver cholesterol concentrations in 23-day-old $\mathrm{Dhcr} 7^{+/-}$and $\mathrm{Dhcr}^{++/}$pups were identical $(2.7 \pm 0.4 \mathrm{mg} / \mathrm{g}$ vs. $2.8 \pm 0.6 \mathrm{mg} / \mathrm{g}$, respectively; $n=4$ ) and were similar in composition to newborn $D h c r 7^{+/-}$and $D h c r 7^{+/+}$livers. Unlike liver, however, cholesterol levels in $\mathrm{Dhcr} 7^{+/-}$and $\mathrm{Dhcr} 7^{+/+}$mouse brains increased threefold to fourfold in the first 3 weeks of life, while desmosterol concentrations fell nearly tenfold (Table 2). Except for subtly elevated 7DHC levels, heterozygous animals appeared otherwise normal, so there was only a minor biochemical phenotype associated with the effect of haploinsufficiency on Dhcr7 activity.

HMG-CoA reductase activities and enzyme protein, but not $m R N A$ levels, were markedly reduced in Dhcr $7^{-1-}$ newborns. Consistent with low total sterol concentrations in Dhcr $7^{-/-}$mice, HMG-CoA reductase activities were reduced sixfold in liver and 2.7-fold in brain microsomes (Table 3), while levels of HMG-CoA reductase protein were reduced commensurately (Figure 6a) compared with $\mathrm{Dhcr} 7^{+/-}$and $\mathrm{Dhcr} 7^{+/+}$littermates. Generalized protein degradation, however, was not a feature of the homozygous mice because levels of LDLR (Figure 6b) and $\beta$-actin concentrations appeared to be similar in all animals. In contrast to HMG-CoA reductase activity, mRNA levels for HMG-CoA reductase as well as for HMG-CoA synthase, squalene synthase, LDLR, SREBP-1, and SREBP-2 were similar in $\mathrm{Dhcr}^{-/-}$, $\mathrm{Dhcr} 7^{+/-}$, and $\mathrm{Dhcr} 7^{+/+}$newborns (Figure 7).

$7 D H C$ accelerates catabolism of HMG-CoA-reductase protein. 7DHC, but not cholesterol, reduced levels of steady state $\beta$-galactosidase activity in a dose-dependent manner in

Table 1

Sterol concentrations in whole brain, whole liver, and liver microsomes from newborn $D h c r 7^{-1-}$ compared with pooled $D h c r 7^{+/-}$and wild-type mice

Sterol

Cholesterol
7DHC + 8DHCC
Desmosterol
7-Dehydro-
desmosterol
Total sterols
$\%$ 7DHC + 8DHC

$$
\begin{gathered}
-/- \\
(n=4)
\end{gathered}
$$$$
0.46 \pm 0.10^{\mathrm{A}}
$$$$
1.64 \pm 0.92^{\mathrm{A}}
$$$$
-
$$$$
0.42 \pm 0.14^{\mathrm{A}}
$$$$
2.52 \pm 1.13^{\mathrm{A}}
$$$$
80 \pm 4
$$

Whole brain

$$
\begin{gathered}
+/- \text { and }+/+ \\
(n=14)
\end{gathered}
$$$$
\mathrm{mg} / \mathrm{g} \text { wet weight }(\text { mean } \pm \mathrm{SD} \text { ) }
$$$$
3.41 \pm 0.48
$$$$
0.03 \pm 0.02^{\mathrm{D}}
$$$$
0.81 \pm 0.12
$$$$
-
$$

$$
\begin{gathered}
4.25 \pm 0.59 \\
0.6 \pm 0.4^{\mathrm{F}}
\end{gathered}
$$

$0.58 \pm 0.47^{\mathrm{A}}$
$0.39 \pm 0.23^{\mathrm{A}}$

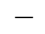

$-$

$1.02 \pm 0.66^{\mathrm{A}}$

$47 \pm 12^{\mathrm{A}}$
Whole liver

$$
\begin{gathered}
+/- \text { and }+/+ \\
(n=14)
\end{gathered}
$$$$
3.19 \pm 0.77
$$$$
0.01 \pm 0.02^{\mathrm{E}}
$$$$
-
$$

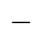

$3.20 \pm 0.86$
$0.5 \pm 0.70$
Liver microsomes

$\begin{array}{cc}-/- & +/- \text { and }+/ \\ (n=3) & (n=4) \\ \mu \mathrm{g} / \text { mg protein } & (\text { mean } \pm \mathrm{SD}) \\ 17 \pm 4^{\mathrm{B}} & 55 \pm 11 \\ 10 \pm 4^{\mathrm{B}} & 1 \pm 1 \\ - & - \\ - & -\end{array}$

$27 \pm 8^{\mathrm{A}}$

$44 \pm 20^{B}$

$56 \pm 11$ $0.01 \pm 0.01$

Cholesterol levels in brain and liver from $D h c r 7^{+/-}$and wild-type mice were similar. ${ }^{A} P<0.002$ vs. pooled $D h c r 7^{+/-}$and $D h c r 7^{+/+}$. ${ }^{B} P<0.02$ vs. pooled $D h c r 7^{+/-}$and $\mathrm{Dhcr} 7^{+/+}$. ${ }^{8} 8 \mathrm{DHC} / 7 \mathrm{DHC}$ ratios were $0.12 \pm 0.11$ in liver and $0.09 \pm 0.02$ in brain. $\mathrm{D} 7 \mathrm{DHC}+8 \mathrm{DHC}=0.035 \pm 0.014 \mathrm{mg} / \mathrm{g}\left(\mathrm{Dhcr} 7^{+/-}, n=9\right) \mathrm{vs} .0 .0092 \pm 0.0041$ $\mathrm{mg} / \mathrm{g}$ in $\left(\mathrm{Dhcr}^{+/+}, n=5\right), P<0.005 . \mathrm{E}^{\mathrm{EDHC}}+8 \mathrm{DHC}=0.020 \pm 0.024\left(\mathrm{Dhcr} 7^{+/-}, n=9\right) \mathrm{vs} .0 .010 \pm 0.019\left(\mathrm{Dhcr} 7^{+/+}, n=5\right), P=\mathrm{NS} . \mathrm{F} 7 \mathrm{DHC}+8 \mathrm{DHC}=0.82 \pm 0.27 \%$ $\left(D h c r 7^{+/+}, n=9\right)$ vs. $0.22 \pm 0.11 \%\left(D h c r 7^{+/+}, n=5\right), P<0.001$. 
a

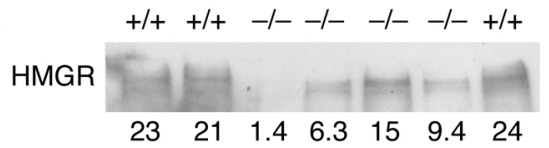

b

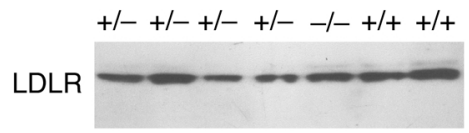

\section{Figure 6}

Immunoblot analysis of $50 \mu \mathrm{g}$ of liver protein for (a) HMG-CoA reductase (HMGR) and (b) LDLR in $D h c r 7^{+/+}, D h c r 7^{+/-}$, and $D h c r 7^{-/-}$ newborn mice demonstrating significantly reduced levels of HMGCoA but not LDLR protein in homozygous animals. Relative intensities of each band normalized to $\beta$-actin are listed below the blots. Levels of $\beta$-actin present in each lane were nearly identical, indicating equal loading and transfer (not shown).

$\mathrm{CHO}$ cells transfected with the $H M G$ al construct (Figure 8). Incubating these cells for 24 hours with $10-20 \mu \mathrm{g} / \mathrm{ml}$ 7DHC raised their 7DHC/cholesterol ratio to levels similar to those measured in the livers of $D h c r 7^{-/-}$mice while reducing activity to $40-50 \%$ of pretreatment values. After a 24-hour incubation following the addition of $1 \mu \mathrm{g} / \mathrm{ml}$ and $10 \mu \mathrm{g} / \mathrm{ml}$ 7DHC to the culture medium (Figure 9), HMG-CoA reductase half-lives were reduced to $3.8 \pm 0.2$ and $2.5 \pm 0.4$ hours, respectively, compared with $9.2 \pm 2.3$ hours in cells grown without exogenous precursor sterol $(P<0.05)$. Similarly, HMGal half-life, $5.0 \pm 0.7$ hours in control cells, was shortened to $2.7 \pm 0.2$ hours and $2.0 \pm 0.4$ hours $(P<0.005)$ in cells incubated with 1 and $10 \mu \mathrm{g} / \mathrm{ml}$ 7DHC, respectively (Figure 10).

Suppressing hydroxylation of the sterol side chain had no effect on the stability of HMGal. Half-lives measured in cells incubated for 24 hours in the presence and absence of $30 \mu \mathrm{M}$ ketoconazole were $4.1 \pm 0.4$ and $5.0 \pm 0.7$, respectively $(P=\mathrm{NS})$, while half-lives in cells grown under identical conditions but after adding $10 \mu \mathrm{g} / \mathrm{ml} 7 \mathrm{DHC}$ were $2.6 \pm 0.1$ and $2.0 \pm 0.4$ hours, respectively $(P=\mathrm{NS})$.

\section{Discussion}

In tissues from $\mathrm{Dhcr} 7^{-/-}$mice, despite the application of a very sensitive and specific technique for the amplification and detection of the transcript for the 3 '-end of Dhcr 7 , none could be found, no Dhcr7 immunoreactive protein was observed, and Dhcr7 enzyme activity could not be detected. Furthermore, $D h c r 7$ mRNA levels and Dhcr7 activities in $D h c r 7^{+/-}$mice were reduced by approximately $50 \%$ compared with their $\mathrm{Dhcr} 7^{+/+}$littermates (Figures 1 and 3 ). Thus, gene targeting was successful, and $D h c r 7^{\Delta E x} 8$ is a null allele unable to reduce $7 \mathrm{DHC}$ to cholesterol. The targeted mouse recapitulated most of the biochemical defects described in SLOS with 7DHC levels elevated 30- to 40-fold, and cholesterol and total sterol concentrations were markedly reduced. In addition, because the biosynthesis of desmosterol requires the reduction of a $\Delta^{7}$ double bond, 7-dehydrodesmosterol, a compound that retains double bonds at both C-7,8 and C-24,25 accumulated in the brains of $\mathrm{Dhcr}^{-/-}$pups (Table 1). Unlike SLOS, however, in which 8DHC and 7DHC concentrations are nearly equal $(16,20), 8 \mathrm{DHC} / 7 \mathrm{DHC}$ ratios in newborn $D h c r 7^{-/-}$mice were closer to 0.1 (Table 1).

The cholesterol/7DHC ratios in livers of newborn homozygous mice were considerably higher than ratios noted in the most severely affected children with SLOS, that is in those individuals predicted to be without DHCR7 activity $(8,18,20)$. This result suggests that the fetal mouse receives a greater proportion of its cholesterol from its mother than does the human fetus, in agreement with numerous observations that maternal cholesterol is obligate for murine (41-43) but not for human (44) development and that considerable amounts of maternal cholesterol are probably transferred to the fetus early in rodent gestation $(45,46)$. The gross structural features of most organs are set within the first 7-10 gestational days in rats and mice. Thus, using atherogenic diets to raise plasma cholesterol levels in pregnant rats being treated with DHCR7 inhibitors probably enabled the mothers to transfer enough extra cholesterol to the fetuses to abolish most abnormal development (47). Because mice normally have much higher plasma cholesterol levels than rats, one has difficulty in generating fetal mice with severe abnormalities using these same inhibitors (48). Elevated cholesterol transfer from mother to fetus early

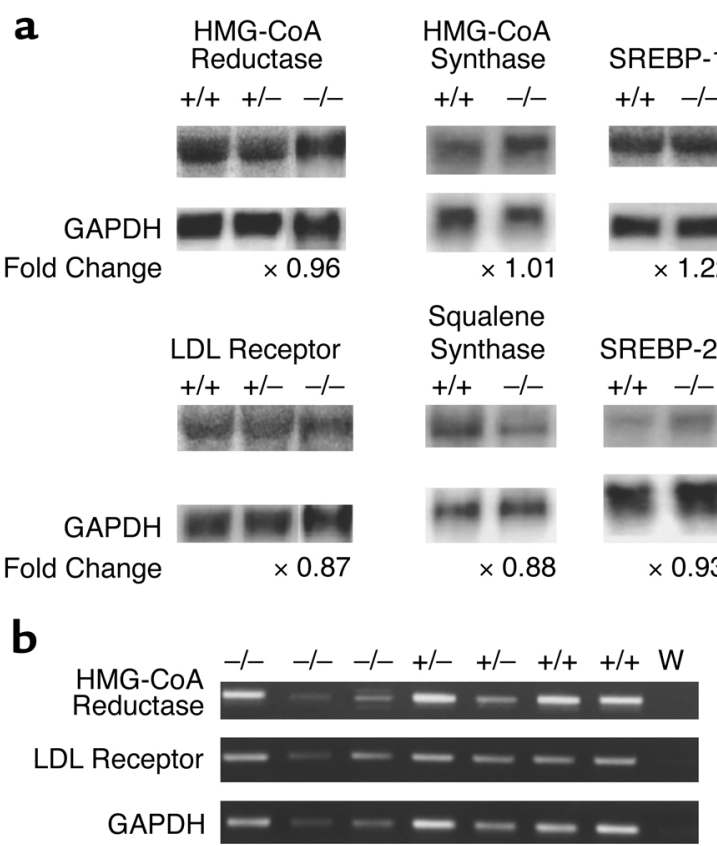

\section{Figure 7}

Northern blot analysis of (a) hepatic HMG-CoA reductase, HMGCoA synthase, squalene synthase, LDLR, SREBP-1, and SREBP-2, and (b) RT-PCR-amplified brain HMG-CoA reductase and LDLR mRNA extracted from $D h c r 7^{-/-}, D h c r 7^{+/-}$, and $D h c r 7^{+/+}$newborn mice, demonstrating that expression of all of the genes is the same in the three genotypes. Intensities in both $\mathbf{a}$ and $\mathbf{b}$ were normalized to GAPDH mRNA. These are representative samples of blots carried out in three $D h c r 7^{-1-}$ mice. 


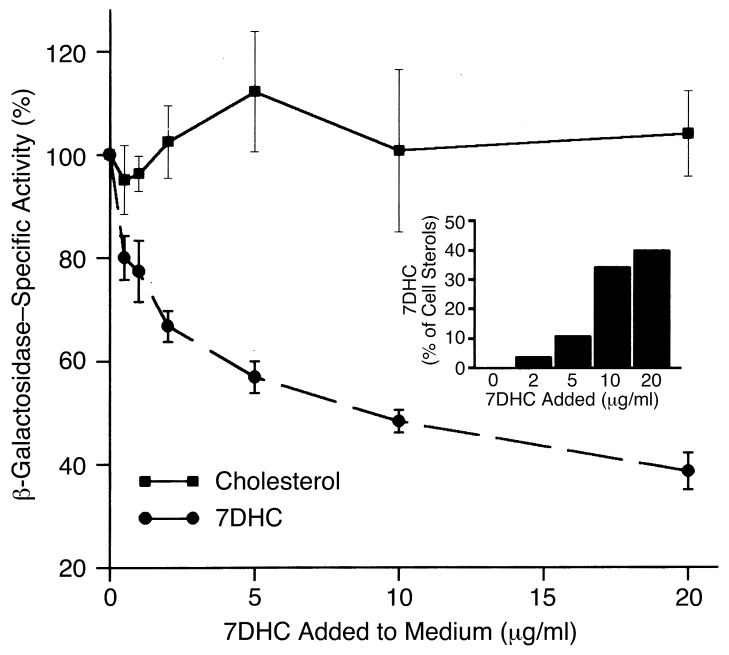

Figure 8

$\beta$-galactosidase activity in $\mathrm{CHO}$ cells transfected with the HMGal construct and driven by the galactosidase promoter. Cells were incubated for 24 hours with increasing concentrations of either 7DHC or cholesterol before determining activity. Because HMG CoA reductase activity is known to be proportional to HMGal activity in this system, these results demonstrate that 7DHC, but not cholesterol, causes excessive destruction of HMG CoA reductase enzyme protein.

in gestation is also likely to be the reason that the Dhcr $7^{-/-}$mice did not develop more of the SLOS-like craniofacial and limb abnormalities.

Although embryonic lethality was not noted in homozygous mice, some developmental abnormalities including incomplete lung development, distended bladders, and cleft palates were seen and all $\mathrm{Dhcr} 7^{-/-}$ mice died within 18 hours of birth from "failure to thrive" with respiratory failure. While palatal clefting and lung abnormalities are found in nearly half of all SLOS patients, the latter usually consist of lobular defects while cellular immaturity has not as yet been reported (49). The exact molecular pathways by which alterations in sterol composition perturb development are not entirely certain but two possibilities seem relevant to this study. Development of lung and bladder, and a number of other organ systems, depends on the sonic hedgehog/patched/smoothened/Gli protein family pathway $(50,51)$ and inappropriate signaling resulting from $S h b$ gene modification leads to abnormal epithelial/mesenchymal interactions (50) and defective lung development in mice (52). Because proper functioning of Shh requires cholesterol (53) and $7 \mathrm{DHC}$ does not permit Shh to be activated $(21,54)$, it was not surprising to find abnormal development in organs that use this signal pathway. Unlike lung and bladder, palatal clefting, noted in $50 \%$ of children with SLOS (8) and $12 \%$ of $\mathrm{Dhcr} 7^{-/}$mice, may be somewhat dependent on abnormal folate metabolism (55). The folate receptor is a glycosylphosphatidylinositol-bound protein complex probably sorted to caveolae or other regions of the cell membrane having a high sterol content and that might be specially sensitive to lipid com- position (56). For instance, SLOS fibroblasts grown in a cholesterol-free medium so as to increase their 7DHC concentration develop membrane-specific defects including increased fluidity and reduced hydrolysis of membrane phosphoinositol (57), all of which might contribute to palatal clefting.

Sterol biosynthesis is suppressed in the average child with SLOS $(16,22,23,25)$. Biosynthesis is also reduced by similar amounts in $\mathrm{Dhrc} 7^{-/-}$mice as percentage of reductions in liver total sterols, HMG-CoA reductase protein levels, and HMG-CoA reductase activities (68\%, $64 \%$, and $83 \%$, respectively) are comparable. Similar differences were also noted in the mouse brain, with the exception that the magnitude of HMG-CoA reductase activities in the brains of all mice were several-fold higher than those noted in the liver. This greater activity reflects the increased need for cholesterol by the CNS soon after birth, illustrated by the fourfold rise in brain, but not liver, cholesterol in 23-day-old compared with newborn mice (Tables 1 and 2). Markedly elevated HMG-CoA reductase activity also explain why, compared with other organs, cholesterol and total sterol deficits are much larger in the brains of both $\mathrm{Dhcr} 7^{-/-}$ mice and severely affected human fetuses (16).

In contrast to activities and protein concentrations, mRNA levels for HMG-CoA reductase, and for number of other genes critical for cholesterol synthesis and metabolism, appeared to be similar in all of the newborn mice (Figure 7). Cholesterol homeostasis is normally maintained by a tightly controlled coordinate regulation of a number of genes modulated, for the most
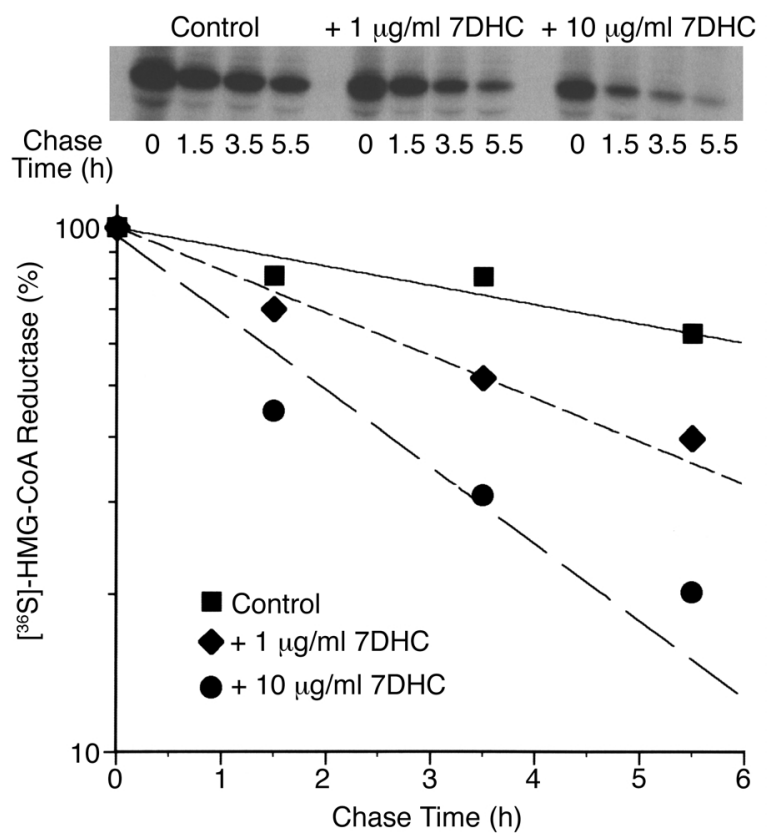

\section{Figure 9}

The percentage of $\left[{ }^{35} \mathrm{~S}\right]-\mathrm{HMG}-\mathrm{CoA}$ reductase remaining 1.5, 3.5, and 5.5 hours after a chase with unlabeled methionine in $\mathrm{CHO}$ cells incubated for 24 hours in the presence or absence of 1 and 10 $\mu \mathrm{g} / \mathrm{ml}$ 7DHC, demonstrating a dose-dependent acceleration of enzyme catabolism by 7DHC. 

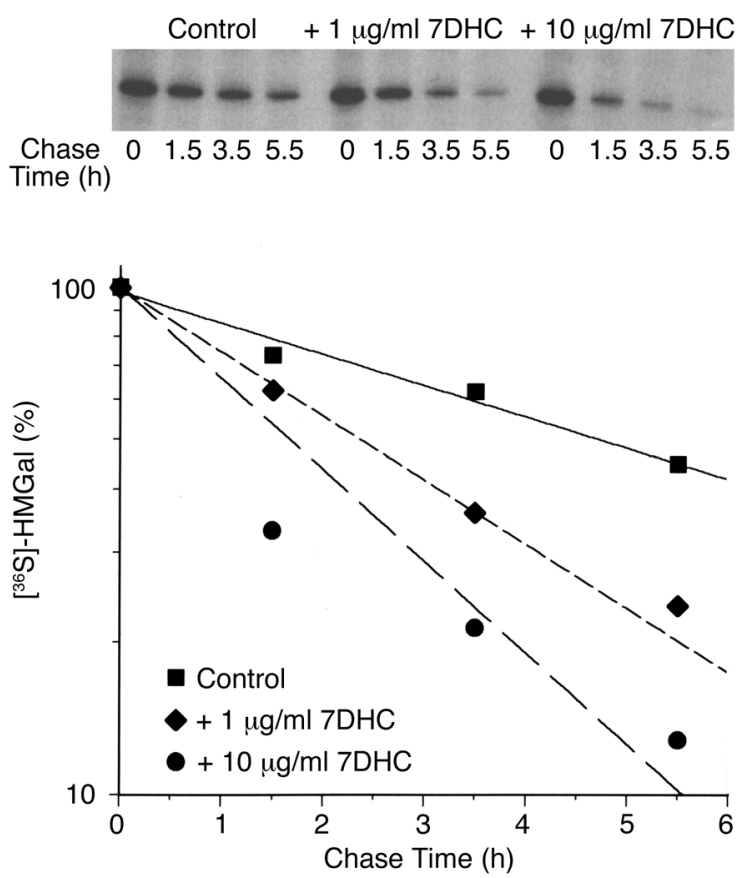

Figure 10

The percentage of $\left[{ }^{35} \mathrm{~S}\right]$-HMGal remaining $1.5,3.5$, and 5.5 hours after a chase with unlabeled methionine in $\mathrm{CHO}$ cells incubated for 24 hours in the presence or absence of 1 and $10 \mu \mathrm{g} / \mathrm{ml} 7 \mathrm{DHC}$, demonstrating a dose-dependent acceleration of HMG CoA reductase enzyme protein catabolism by 7DHC.

part, by the microsomal protein SREBP-2. When intracellular cholesterol levels are sensed as being too low, SREBP-2 is cleaved from the endoplasmic reticulum (ER), releasing a nuclear transcription factor that upregulates expression of HMG-CoA reductase, HMG-CoA synthase, squalene synthase, LDLR, and SREBP-2 (58). Thus, for example, treating rats with the squalene synthase inhibitor zaragozic acid and reducing hepatic cholesterol levels by $40 \%$ induces a fourfold to fivefold increase in HMG-CoA reductase and LDLR transcription rates, mRNA levels, and protein concentrations, and in HMG-CoA reductase activities $(59,60)$. Yet, in Dhcr $7^{-/-}$mice, despite similar reductions in total sterol concentrations and much greater reductions in tissue cholesterol levels, the SREBP-2-modulated pathway seems not to be activated (Figure 7). It may be that 7 DHC perturbs $(57,61)$ the ER membrane, making cleavage of the active nuclear transcription factor more difficult, or changes membrane properties so as to prevent the cycling of SCAP to the Golgi apparatus so that it can be modified and activated (62). However, because LDLR mRNA and protein levels were similar in both affected, wild-type, and heterozygous mice, high levels of 7DHC seem not to interfere with translation.

Unchanged mRNA levels would not, under any circumstances, explain why HMG-CoA reductase protein levels are depressed in homozygous mice or why de novo sterol synthesis is inhibited. But, the combination of normal HMG-CoA reductase and LDLR mRNA and reduced protein levels for HMG-CoA reductase, but not for LDLR or $\beta$-actin, suggested that 7DHC might be accelerating the degradation of HMG-CoA reductase itself. We assayed the effect of 7DHC on the catabolism of HMG-CoA reductase using a well-established in vitro model that employs $\mathrm{CHO}$ cells transfected with the HMGal construct, which consists of the transmembrane region of HMG-CoA reductase fused to the reporter $\beta$-galactosidase gene and its promoter. This portion of the HMG-CoA reductase protein is sufficient to initiate the HMG-CoA reductase proteolytic cascade, which, at the same time, also degrades $\beta$-galactosidase. Thus, in this system, HMG-CoA reductase activity and protein levels are both proportional to $\beta$-galactosidase activity $(34,38)$. Furthermore, because expression is driven by the galactosidase, not the HMGCoA reductase, promoter assays are carried out under conditions of constant gene expression unrelated to either cholesterol or isoprenoid concentrations.

The addition of sufficient 7DHC to raise the 7DHC/cholesterol ratio to a level nearly equal to that in the livers of $\mathrm{Dhcr}^{-/-}$mice suppressed steady-state $\beta$-galactosidase activity by about $50 \%$ (Figure 8 ), a value similar to the reduction in HMG-CoA reductase activity and protein noted in these animals. In contrast to 7DHC, cholesterol had no effect on activity. These results, taken together, suggest that 7DHC probably destabilizes HMG-CoA reductase enzyme. We were able to prove that this is indeed the mechanism that causes reduced sterol biosynthesis in $\mathrm{Dhcr} 7^{-/-}$mice and in patients with SLOS by incubating $\mathrm{CHO}$ cells with 7DHC and finding that the half-lives of HMG-CoA reductase (Figure 9) and HMGal (Figure 10) both decreased threefold when cellular 7DHC increased to about $30 \%$ of total sterols.

HMG-CoA reductase is an ER protein that is degraded within its transmembrane region by a membrane-bound cysteine protease $(35,63)$. It normally has a half-life of only a few hours, and its stability is reduced by $\mathrm{Ca}^{2+}$ depletion (38), perhaps involving a specific Ca transporter (64), and by the addition of mevalonate or mevalonate-derived sterols $(65,66)$. Nevertheless, in the Dhcr $7^{-1-}$ mouse and in SLOS, despite reduced tissue total sterol concentrations and plasma mevalonate levels (24), HMG-CoA reductase protein appears to be degraded at a highly accelerated rate. This result, in turn, suggests that 7DHC has an effect within the ER membrane contrary to that of cholesterol or isoprenoid cholesterol precursors, and in some manner activates the proteolytic

\section{Table 2}

Brain sterols in 23-day-old $D h c r 7^{+/-}$and $D h c r 7^{+/+}$mice

$\begin{array}{lcc}\text { Sterol } & +/-(n=4) & +/+(n=4) \\ & & \mathrm{mg} / \mathrm{g} \text { wet weight }(\text { mean } \pm \text { SD }) \\ \text { Cholesterol } & 15.5 \pm 0.9 & 15.8 \pm 1.3 \\ \text { Desmosterol } & 0.14 \pm 0.01 & 0.15 \pm 0.01 \\ \text { 7DHC } & 0.024 \pm 0.07^{\mathrm{A}} & 0.012 \pm 0.003\end{array}$

AP $<0.02$ vs. Dhcr ${ }^{+/+}$. 


\section{Table 3}

HMG-CoA reductase activity in liver and brain microsomes from Dhcr $7^{-/-}$compared with $\mathrm{Dhcr} 7^{+/+}$newborn mice

\begin{tabular}{|c|c|c|}
\hline & & $+/+$ \\
\hline & \multicolumn{2}{|c|}{$\mathrm{pmol} / \mathrm{min} / \mathrm{mg}$ protein $($ mean $\pm \mathrm{SD})$} \\
\hline Liver & $19 \pm 13(n=7)^{\mathrm{A}, \mathrm{B}}$ & $112 \pm 70(n=15)^{\mathrm{C}}$ \\
\hline Brain & $169 \pm 76(n=8)^{\mathrm{A}}$ & $457 \pm 224(n=14)$ \\
\hline
\end{tabular}

process. Although it has not been well studied, replacing cholesterol with 7DHC has a number of effects on membranes, including increasing their thickness and fluidity as well as their permeability to Ca ions (57). In contrast to 7DHC, ketoconazole, an inhibitor of sterol side-chain hydroxylation that mitigates the suppression of HMGCoA reductase activity by 7DHC in fibroblast cultures (22), did not affect the HMGal half-life. This latter result suggests that, while 27 -hydroxylated sterols may well be important inhibitors of HMG-CoA reductase expression (67), they probably have little effect on enzyme stability in physiologic concentrations.

Thus, the 7DHC that accumulates in patients with SLOS accelerates proteolysis of HMG-CoA reductase enzyme protein, thereby depriving the developing organism of needed sterols. Although this effect might be protective, forestalling even more massive accumulations of a possibly toxic precursor such as 7DHC, it is just as likely to be deleterious. This would be especially disadvantageous for children with mutations that retain some DHCR7 activity (18) by suppressing the production of 7DHC and further restricting the amount of cholesterol available prenatally (68). The newborn $\mathrm{Dhcr} 7$-null mouse is, for many purposes, a good model for SLOS. However, because it does not demonstrate many of the more common abnormalities noted in SLOS, it will have to be further manipulated (48) to create a system to study abnormal development. Nevertheless, this mouse has been especially helpful because it has permitted identification of one of the major mechanisms that suppresses sterol synthesis in children with SLOS.

Note added in proof. During preparation of this manuscript Wassif et al. published a description of a SLOS/RSH mouse (69). Using a different targeting strategy, they created an animal without apparent Dhcr7 activity but with impaired glutamate uptake by frontal cortex neurons that demonstrated nearly identical sterol concentrations and phenotype as the $D h c r 7^{\triangle E x} 8$ mice. Both models have been described before in abstract form (70-72).

\section{Acknowledgments}

This work was supported by a grants from the Department of Veterans Administration Research Service (to G.S. Tint and to G. Salen), grant $9950855 \mathrm{~V}$ from the American Heart Association, Florida/Puerto Rico Affiliate (to G.C. Ness), NIH grant HL-4263 (to N. Maeda), training grant T32NS07431 (to H. Waage-Baudet), grants from Fonds zur Förderung der wissenschaftlichen Forschung (P14112-MOB to H. Glossmann) and the Jubiläumsfond der Österreichischen Nationalbank (to H. Glossmann). The authors also wish to thank Bibiana Pcolinsky for her excellent technical assistance.

1. Hoffmann, G., et al 1986. Mevalonic aciduria: an inborn error of cholesterol and nonsterol isoprene biosynthesis. N. Engl. J. Med. 314:1610-1614

2. Clayton, P., Mills, K., Keeling, J., and FitzPatrick, D. 1996. Desmosterolosis: a new inborn error of cholesterol biosynthesis. Lancet. 348:404.

3. Kelley, R.I., et al. 1999. Abnormal sterol metabolism in patients with Conradi-Hunermann-Happle syndrome and sporadic lethal chondrodysplasia punctata. Am. J. Med. Genet. 83:213-219.

4. Braverman, N., et al. 1999. Mutations in the gene encoding 3 betahydroxysteroid- $\Delta^{8}, \Delta^{7}$-isomerase cause X-linked dominant ConradiHunermann syndrome. Nat. Genet. 22:291-294.

5. König, A., Happle, R., Bornholdt, D., Engel, H., and Grzeschik, K.-H. 2000. Mutations in the NSDHL gene, encoding a $3 \beta$-hydroxysteroid dehydrogenase, cause CHILD syndrome. Am. J. Med. Genet. 90:339-346.

6. Grange, D.K., Kratz, L.E., Braverman, N.E., and Kelley, R.I. 2000. CHILD syndrome caused by deficiency of $3 \beta$-hydroxysteroid- $\Delta^{8}, \Delta^{7}$-isomerase. Am. J. Med. Genet. 90:328-335.

7. Lowry, R.B., and Yong, S.-L. 1980. Borderline intelligence in the SmithLemli-Opitz syndrome. Am. J. Med. Genet. 5:137-143.

8. Cuniff, C., Kratz, L.E., Moser, A., Natowicz, M.R., and Kelley, R.I. 1997. Clinical and biochemical spectrum of patients with RSH/Smith-LemliOpitz syndrome and abnormal cholesterol metabolism. Am. J. Med. Genet. 68:263-269.

9. Witsch-Raumgartner, M., et al. 2001. Frequency gradients of DHCR7 mutations in patients with Smith-Lemli-Opitz syndrome in Europe: evidence for different origins of common mutations. Eur. J. Hum. Genet. 9:45-50.

10. Smith, D.W., Lemli, L., and Opitz, J.M. 1964. A newly recognized syndrome of multiple congenital anomalies. J. Pediatr. 64:210-217.

11. Curry, C.J.R., et al. 1987. Smith-Lemli-Opitz syndrome-type II: multiple congenital anomalies with male pseudohermaphroditism and frequent early lethality. Am. J. Med. Genet. 26:45-57.

12. Tint, G.S., et al. 1994. Defective cholesterol biosynthesis associated with the Smith-Lemli-Opitz syndrome. N. Engl. J. Med. 330:107-113.

13. Shefer S., et al. 1995. Markedly inhibited 7-dehydrocholesterol- $\Delta^{7}$-reductase activity in liver microsomes from Smith-Lemli-Opitz homozygotes. J. Clin. Invest. 96:1779-1785.

14. Moebius, F.F., Fitzky, B.U., Lee, J.N., Paik, Y.-K., and Glossmann, H. 1998. Molecular cloning and expression of the human $\Delta^{7}$-sterol reductase. Proc. Natl. Acad. Sci. USA. 95:1899-1902.

15. Fitzky, B.U., et al. 1998. Mutations in the $\Delta^{7}$-sterol reductase gene in patients with the Smith-Lemli-Opitz syndrome. Proc. Natl. Acad. Sci. USA. 95:8181-8186.

16. Tint, G.S., et al. 1995. Markedly increased concentrations of 7-dehydrocholesterol combined with low levels of cholesterol are characteristic of the Smith-Lemli-Opitz syndrome. J. Lipid Res. 36:89-95.

17. Kelley, R.I. 1995. Diagnosis of Smith-Lemli-Opitz syndrome by gas chromatography/mass spectrometry of 7-dehydrocholesterol in plasma, amniotic fluid and cultured skin fibroblasts. Clin. Chem. Acta. 236:45-58.

18. Witsch-Baumgartner, M., et al. 2000. Mutational spectrum in the $\Delta 7$ sterol reductase gene and genotype-phenotype correlation in 84 patients with the Smith-Lemli-Opitz syndrome. Am. J. Hum. Genet. 66:402-412.

19. Porter, J.A., Young, K.E., and Beachy, P.A. 1996. Cholesterol modification of hedgehog signaling proteins in animal development. Science. 274:255-259.

20. Tint, G.S., et al. 1995. Correlation of severity and outcome correlate with plasma sterol levels in variants of the Smith-Lemli-Opitz syndrome. J. Pediatr. 127:82-87.

21. Incardona, J.P., Gaffield, W., Kapur, R.J., and Roelink, H. 1998. The teratogenic Veratrum alkaloid cyclopamine inhibits Sonic hedgehog signal transduction. Development. 125:3553-3562.

22. Honda, M., et al. 1998. 7-Dehydrocholesterol down-regulates cholesterol biosynthesis in cultured Smith-Lemli-Opitz syndrome skin fibroblasts. J. Lipid Res. 39:647-657.

23. Tint, G.S., et al. 1997. The Smith-Lemli-Opitz syndrome: a potentially fatal birth defect caused by a block in the last enzymatic step in cholesterol biosynthesis. In Subcellular biochemistry: cholesterol: its metabolism and functions in biology and medicine. Volume 28. R. Bittman, editor. Plenum Press. New York, New York, USA. 117-143.

24. Honda, M., et al. 2000. Regulation of cholesterol biosynthetic pathway in patients with the Smith-Lemli-Opitz syndrome. J. Inherit. Metab. Dis. 23:464-474. 
25. Steiner, R.D., Linck, L.M., Flavell, D.P., Lin, D.S., and Connor, W.E. 2000. Sterol balance in the Smith-Lemli-Opitz syndrome: reduction in whole body cholesterol synthesis and normal bile acid production. J. Lipid Res. 41:1437-1447.

26. Shehee, W.R., Oliver, P., and Smithies, O. 1993. Lethal thalassemia after insertional disruption of the mouse major adult beta-globin gene. Proc. Natl. Acad. Sci. USA. 90:3177-3181.

27. Batta, A.K., Tint, G.S., Abuelo, D., Shefer, S., and Salen, G. 1995. Identification of 8-dehydrocholesterol (cholesta-5,8-dien-3 $\beta$-ol) in patients with Smith-Lemli-Opitz syndrome. J. Lipid. Res. 36:705-713.

28. Honda, M., et al. 1996. Measurement of $3 \beta$-hydroxysteroid $\Delta^{7}$-reductase activity in cultured skin fibroblasts utilizing ergosterol as a substrate: a new method for the diagnosis of the Smith-Lemli-Opitz syndrome. $J$. Lipid Res. 37:2433-2438.

29. Nguyen, L.B., et al. 1990. A molecular defect in hepatic cholesterol biosynthesis in sitosterolemia with xanthomatosis. J. Clin. Invest. 86:923-931.

30. Wu, J., Zhu, Y.H., and Patel, S.B. 1999. Cyclosporin-induced dyslipoproteinemia is associated with selective activation of SREBP-2. Am. J. Physiol. 277:E1087-E1094.

31. Chambers, C.M., and Ness, G.C. 1998. Dietary cholesterol regulates hepatic 3-hydroxy-3-methylglutaryl coenzyme A reductase gene expression in rats primarily at the level of translation. Arch. Biochem. Biophys. 354:317-322.

32. Ness, G.C., Sample, C.E., Smith, M., Pendleton, L.C., and Eichler, D.C. 1986. Characteristics of rat liver microsomal 3-hydroxy-3-methylglutaryl-coenzyme A reductase. Biochem. J. 233:167-172.

33. Ness, G.C., and Zhao, Z. 1994. Thyroid hormone rapidly induces hepatic LDL receptor mRNA levels in hypophysectomized rats. Arch. Biochem. Biophys. 315:199-202.

34. Skalnik, D.G., Narita, H., Kent, C., and Simoni, R.D. 1988. The membrane domain of 3-hydroxy-3-methylglutaryl-coenzyme A reductase confers endoplasmic reticulum localization and sterol regulated degradation onto $\beta$-galactosidase. J. Biol. Chem. 263:6836-6841.

35. Jingami, H., Brown, M.S., Goldstein, J.L., Anderson, R.G.W., and Luskey, K.L. 1987. Partial deletion of membrane-bound domain of 3-hydroxy-3 methylglutaryl coenzyme A reductase eliminates sterol-enhanced degradation and prevents formation of crystalloid endoplasmic reticulum. $J$. Cell Biol. 104:1693-1704

36. Rothblat, G.H., Arbogast, L.Y., Ouellette, L., and Howard, B.V. 1976. Preparation of delipidized serum protein for use in cell culture systems. In Vitro. 12:554-557.

37. Lowry, O.H., Rosebrough, N.J., Farr, A.L., and Randall, R.J. 1951. Protein measurements with the Folin phenol reagent. J. Biol. Chem. 193:265-275.

38. Roitelman, J., Bar-Nun, S. Inoue, S, and Simoni, R.D. 1991. Involvement of calcium in the mevalonate-accelerated degradation of 3-hydroxy-3methylglutaryl-CoA reductase. J. Biol. Chem. 266:16085-16091.

39. Bae, S.-H., Lee, J.N., Fitzky, B.U., Seong, J., and Paik, Y.-K. 1999. Cholesterol synthesis from lanosterol. Molecular cloning, tissue distribution, expression, chromosomal localization, and regulation of 7-dehydrocholesterol reductase, a Smith-Lemli-Opitz syndrome-related protein. J. Biol. Chem. 274:14624-14631.

40. Talbot, C.L., et al. 1999. Quantitation and localization of ENaC subunit expression in fetal, newborn, and adult mouse lung. Am. J. Respir. Cell Mol. Biol. 20:398-406.

41. Farese, R.V., Jr., Ruland, S.L., Flynn, L.M., Stokowski, R.P., and Young, S.G. 1995. Knockout of the mouse apolipoprotein B genes results in embryonic lethality in homozygotes and protection against diet-induced hypercholesterolemia in heterozygotes. Proc. Natl. Acad. Sci. USA. 92:1774-1778.

42. Raabe, M., et al. 1998. Knockout of the abetalipoproteinemia gene in mice - reduced lipoprotein secretion in heterozygotes and embryonic lethality in homozygotes. Proc. Natl. Acad. Sci. USA. 95:8686-8691.

43. Herz, J., and Farese, R.V. 1999. The LDL receptor gene family, apolipoprotein B and cholesterol in embryonic development. J. Nutr. 129:473S-475S.

44. Linton, M.F., Farnese, R.V., Jr., and Young, S.G. 1993. Familial hypobetalipoproteinemia. J. Lipid Res. 34:521-541.

45. Chevallier, F. 1964. Transferts et synthèse du cholesterol chez le rat au course de sa croissance. Biochim. Biophys. Acta. 84:316-339.

46. McConihay, J.A., Honkomp, A.M., Granholm, N.A., and Woollett, L.A. 2000. Maternal high density lipoproteins affect fetal mass and extra-embryonic fetal tissue sterol metabolism in the mouse. J. Lipid Res. 41:424-432.

47. Roux, C., Dupuis, R., Horvath, C., and Talbot, J.-N. 1980. Teratogenic effect of an inhibitor of cholesterol synthesis (AY 9944) in rats: correlation with maternal cholesterolemia. J. Nutr. 110:2310-2312.

48. Lanoue, L., et al. 1997. Limb, genital, CNS and facial malformations result from gene/enviroment-induced cholesterol deficiency: further evidence for a link to Sonic Hedgehog. Am. J. Med. Genet. 73:24-31.

49. Kelley, R.I., and Hennekam, R.C.M. 2000. The Smith-Lemli-Opitz syndrome. J. Med. Genet. 37:321-335.

50. Bitgood, M.J., and McMahon, A.P. 1995. Hedgehog and Bmp genes are coexpressed at many diverse sites of cell-cell interaction in the mouse embryo. Dev. Biol. 172:126-138.

51. Hogan, B.L., et al. 1997. Branching morphogenesis of the lung: new models for a classical problem. Cold Spring Harb. Symp. Quant. Biol. 62:249-256.

52. Pepicelli, C.V., Lewis, P.M., and McMahon, A.P. 1998. Sonic hedgehog regulates branching morphogenesis in the mammalian lung. Curr. Biol. 8:1083-1086

53. Cooper, M.K., Porter, J.A., Young, K.E., and Beachy, P.A. 1998. Teratogenmediated inhibition of target tissue response to $S h b$ signaling. Science. 280:1603-1607.

54. Gofflot, F., Gaoua, W., Bourguignon, L., Roux, C., and Picard, J.J. 2001. Expression of Sonic Hedgehog downstream genes is modified in rat embryos exposed in utero to a distal inhibitor of cholesterol biosynthesis. Develop. Dynam. 220:99-111.

55. Heil, S.G., van der Put, N.M.J., Trijbels, F.J.M., Gabreels, F.J.M., and Blom H.J. 1999. Molecular genetic analysis of human folate receptors in neural tube defects. Eur. J. Hum. Genet. 7:393-396.

56. Luhrs, C.A., and Slomiany, B.L. 1989. A human membrane-associated folate binding protein is anchored by a glycosylphosphatidylinositol tail. J. Biol. Chem. 264:21446-21449.

57. Tulenko, T.N., LaBelle, E., Boesze-Battaglia, K., Mason, R.P., and Tint, G.S. 1998. A membrane bilayer defect in the Smith-Lemli-Opitz syndrome. FASEB J. 12:A827. (Abstr.)

58. Brown, M.S., and Goldstein, J.L. 1999. A proteolytic pathway that controls the cholesterol content of membranes, cells and blood. Proc. Natl. Acad. Sci. USA. 96:11041-11048.

59. Ness, G.C., Zhao, Z.H., and Keller, R.K. 1994. Effect of squalene synthase inhibition in the expression of hepatic cholesterol biosynthetic-enzymes, LDL receptor, and cholesterol $7 \alpha$ hydroxylase. Arch. Biochem. Biophys. 311:277-285.

60. Lopez, D., Chambers, C.M., Keller, R.K., and Ness, G.C. 1998. Compensatory responses to inhibition of hepatic squalene synthase. Arch. Biochem. Biophys. 351:159-166.

61. Bruckerdorfer, K.R., Demel, R.A., De Gier, J., and Van Deenen, L.L.M. 1969. The effect of partial replacements of membrane cholesterol by other steroids on the osmotic fragility and glycerol permeability of erythrocytes. Biochim. Biophys. Acta. 183:334-345.

62. Nohturfft, A., De Bose-Boyd, R.A., Scheek, S., Goldstein, J.L., and Brown, M.S. 1999. Sterols regulate cycling of SREBP cleavage-activating protein (SCAP) between endoplasmic reticulum and Golgi. Proc. Natl. Acad. Sci. USA. 96:11235-11240.

63. Moriyama, T., Sather, S.K., McGee, T.P., and Simoni, R.D. 1998. Degradation of HMG-CoA reductase in vitro. Cleavage in the membrane domain by a membrane-bound cysteine protease. J. Biol. Chem. 273:22037-22043.

64. Cronin, S.R., Khoury, A., Ferry, D.K., and Hampton, R.Y. 2000. Regulation of HMG-CoA reductase degradation requires the P-type ATPase Cod1p/Spf1p. J. Cell Biol. 148:915-924.

65. Roitelman, J., and Simoni, R.D. 1992. Distinct sterol and non-sterol signals for the regulated degradation of 3-hydroxy-3-methylglutaryl-CoA reductase. J. Biol. Chem. 267:25264-25273.

66. Bradfute, D.L., and Simoni, R.D. 1994. Non-sterol compounds that regulate cholesterogenesis. Analogues of farnesyl pyrophosphate reduce 3hydroxy-3-methylglutaryl-coenzyme A reductase levels. J. Biol. Chem. 269:6645-6650

67. Axelson, M., and Larsson, O. 1995. Low density lipoprotein (LDL) cholesterol is converted to 27 -hydroxycholesterol in human fibroblasts. $J$. Biol. Chem. 270:15102-15110.

68. Gaoua, W., Wolf, C., Chevy, F., Ilien F., and Roux, C. 2000. Cholesterol deficit but not accumulation of aberrant sterols is the major cause of the teratogenic activity in the Smith-Lemli-Opitz syndrome. J. Lipid Res. 41:637-646.

69. Wassif, C.A., et al. 2001. Biochemical, phenotypic and neurophysiogical characterization of a genetic mouse model of RSH/Smith-Lemli-Opitz syndrome. Hum. Mol. Gen. 10:555-564.

70. Tint, G.S., et al. 1999. A mouse model for the Smith-Lemli-Opitz syndrome. Am. J. Hum. Genet. 65:A96. (Abstr.)

71. Tint, G.S., et al. 2000. Cholesterol (CH) metabolism is highly abnormal in the mouse model of Smith-Lemli-Opitz syndrome. Hepatology. 32:387A. (Abstr.)

72. Porter, F.D., et al. 2000. Phenotypic, biochemical, and neurophysiological characterization of a SLOS mouse model. Am.J. Hum. Genet. 67:280. (Abstr.) 